TITLE:

CONTRIBUTIONS TO JAPANESE ASCIDIAN FAUNA XXV. NOTES ON THE VARIATIONS IN BOTRYLLOIDES VIOLACEUS OKA, WITH THE DESCRIPTION OF A NEW SUBSPECIES TENUICOECUS

$\operatorname{AUTHOR}(S)$ :

Tokioka, Takasi

CITATION:

Tokioka, Takasi. CONTRIBUTIONS TO JAPANESE ASCIDIAN FAUNA XXV. NOTES ON THE VARIATIONS IN BOTRYLLOIDES VIOLACEUS OKA, WITH THE DESCRIPTION OF A NEW SUBSPECIES TENUICOECUS. PUBLICATIONS OF THE SETO MARINE BIOLOGICAL LABORATORY 1970, 18(1): 57-59

ISSUE DATE:

1970-09-16

URL:

http://hdl.handle.net/2433/175619

RIGHT: 


\title{
CONTRIBUTIONS TO JAPANESE ASCIDIAN FAUNA XXV. NOTES ON THE VARIATIONS IN BOTRYLLOIDES VIOLACEUS OKA, WITH THE DESCRIPTION OF A NEW SUBSPECIES TENUICOECUS ${ }^{1 \text { ) }}$
}

\author{
TAKASI TOKIOKA \\ Seto Marine Biological Laboratory
}

With 1 Text-figure

OKA (1927) proposed to separate a number of varieties from one another in his Botrylloides violaceus by colour differences. Besides the variation in colouration, some morphological variations have been known in the same species: the size of zooids, the number of stigmatal rows, the level of the anus, the level of the anterior edge of the intestinal loop, and the number of longitudinal plications of the stomach show respective ranges. Noting these variations, I had tried to learn whether or not some correlations exist among these morphological variations including colour differences and some ecological peculiarities. In earlier stages of my research, I could not confirm any positive correlations and simply rejected to separate many colourtypes as varieties (Токіока, 1953, pp. 242-243). Indeed, most of such colourtypes might be of the genetical nature.

However, in 1964, I noticed a very distinct correlation between the greenish colour type and its habitat which is strictly limited to the places effected by the oceanic water and somewhat exposed to the wave action. The morphological characters of this greenish colour type are quite within the range of $B$. violaceus, but the greenish colouration is very distinct, and the correlation between this colouration and the above-mentioned habitat can be confirmed by very many colonies without exception. For this reason, I made my mind to separate the greenish colonies as a distinct species, Botrylloides viride, from B. violaceus. Later, I separated another colour variety, which is living in the tropical waters, as a subspecies marginatus of $B$. violaceus (TokIokA, 1967, p. 160). The very peculiar colour pattern consisting of reddish orange and chocolate brown seems to be correlated with the somewhat larger number of stigmatal rows (TokiokA, 1968, p. 144), and thus the colonies of this colour type might establish a distinct species. The habitat seems to be limited in the very warmer and oceanic waters. However, so far only a few colonies have

1) Contributions from the Seto Marine Biological Laboratory, No. 521.

Publ. Seto Mar. Biol. Lab., XVIII (1), 57-59, $1970 . \quad$ (Article 5) 
been examined. For only this reason, I am still hesitating to separate this colour type definitely and leaving it within $B$. violaceus as a subspecies. The morphology of both $B$. viride and $B$. violaceus marginatus resembles closely that of typical $B$. violaceus, especially in the feature of the second stigmatal row which never reaches dorsally the median line.

On May 25, 1970, when Dr. S. Nishimura, Mr. Chokechai Senawong and I visited a reef of Hatakezima Island, just south of Komaruzima Islet, to study the intertidal fauna and flora, Mr. Senawong, a graduate student of the Zoological Institute, Kyoto University, found a Botrylloides-colony at a shallow place of the sublittoral zone, considerably sheltered from the wave action, but not affected by the stagnant water of the inner part of Tanabe Bay. The colony is incrusting wholly the exterior surface of a worn empty shell of probably Spondylus sp., roughly $60 \mathrm{~mm}$ $\times 50 \mathrm{~mm}$, and partly the interior surface, too. The colony consists of many systems arranged quite similarly as in usual colonies of $B$. violaceus, but the colouration was very attractive when the colony was alive. On the anterior side of the mantle of respective zooids, the part surrounding the branchial aperture was coloured brownish orange, while the portion forming the atrial languet was coloured in dark chocolate brown. Thus, first I thought if this colony was $B$. violaceus marginatus, although the arrangement of two colours, brownish orange and dark chocolate brown, was quite reverse in this colony.

In examining some zooids of the colony, however, I was surprised much at a very peculiar form of the pyloric coecum constantly found in them. This strange feature might be worthy of a specific significance. But at present, only a single colony is available, no definite data are available as to its habitat, and other general morphological features are quite similar with those of $B$. violaceus. For these reasons, the colony is described in this note provisionally as a new subspecies of $B$. violaceus. Before going to the description, I want to express here my hearty thanks to Mr. Senawong for his generostity to submit the specimen to me for exact taxonomical examination.

\section{Botrylloides violaceus tenuicoecus nov.}

The test is so much softened in formalin that it is very difficult to measure the exact thickness; presumably nearly as thick as the length of zooids which are situated mostly perpendicularly. The mantle of zooids is generally pigmented more heavily in the anterior half than in the posterior. Several anterior transverse vessels of the branchial sac are pigmented, too, especially remarkably at each ventral end so that there may be seen in some zooids a series of paired pigment spots along the endostyle. The pigmentation is rather lighter in the part of the colony covering the interior surface of the empty shell. The stomach is bright orange in colour.

Zooids are mostly $2 \mathrm{~mm}$ in length, are constructed generally quite similarly with the typical form of Botrylloides violaceus, and are provided with the gonad in the earlier 
stages of development. The left gonad is situated along the anterior margin (middle or a little ventral) of the intestinal loop and consists in examined zooids of 1 to 8 lobules, while the right one at the level of the anterior margin( middle to pyloric end) of the stomach and consists of 5 to 8 lobules. Twelve to thirteen stigmatal rows on each side, the second row never reaches dorsally the median line. The distribution of stigmata is roughly $\mathrm{D} 3.3 .2 .3 \mathrm{~V}$ near the middle part. The anus is attached to the branchial sac at the level of the 9 th transverse vessel, and the anterior margin of the intestinal loop attains to the 10th transverse vessel; thus the rectum is rather short. The stomach is nearly exposed behind the posterior end of the branchial sac and with nine (rarely ten) longitudinal plications on the surface. The pyloric coecum is very prominent, elongate, curved markedly and distally attenuated.

Remarks: The distally attenuated feature of the pyloric coecum in the present

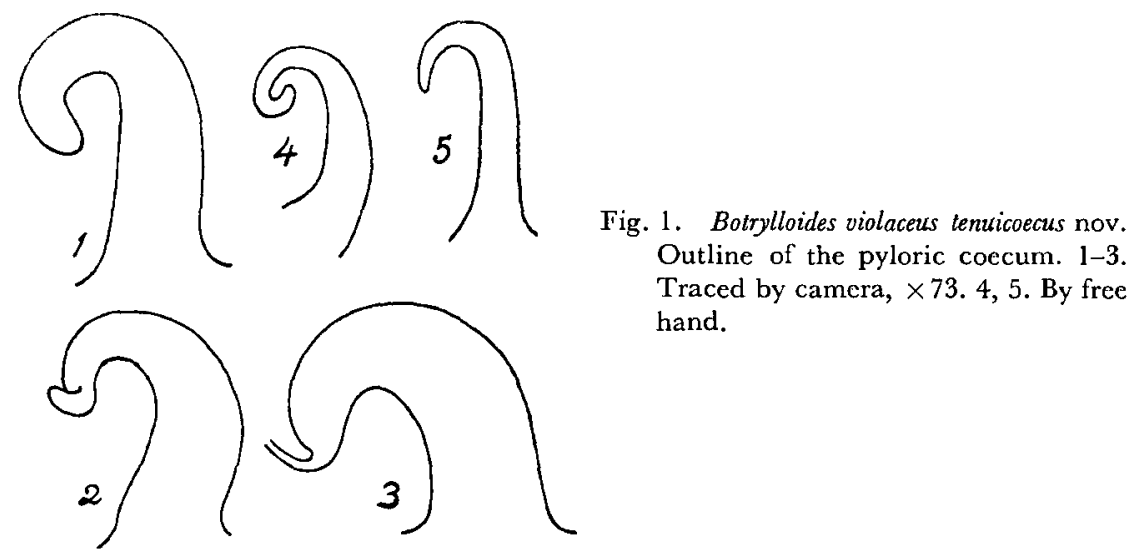

specimen is quite unique. Such an appearance is exceptional not only in the species of Botryllidae but also throughout the members of so-called compound or social styelids.

\section{REFERENCES}

OKА, A. (1927): Zur Kenntnis der japanischen Botryllidae (Vorläufige Mitteilung). Proc. Imp. Acad., Vol. 3, No. 9, pp. 607-609.

ТокіокA, T. (1953): Ascidians of Sagami Bay. Tokyo, pp. 241-243; Pl. 3, figs. 1-2; Pl. 44, figs. 1-5; Pl. 45, figs. 1-4.

(1964): Contributions to Japanese ascidian fauna XXI. Bolrylloides viride n. sp., a new greenish compound ascidian from the vicinity of Seto. Publ. Seto Mar. Biol. Lab., Vol. 12, No. 4, pp. 281-283, 1 text-fig.

(1967): Pacific Tunicata of the United States National Museum. U.S. Nat. Mus. Bull. 251, pp. 156-162, figs. 62-64.

(1968): Contributions to Japanese ascidian fauna XXIII. On Botrylloides violaceus marginatus TокıокA, 1967. Publ. Seto Mar. Biol. Lab., Vol. 16, No. 2, pp. 141-145, 1 text-fig. 